\title{
The Influence of a Culture of Cooperation, a Culture of Discipline and Classroom Management Skills on the Achievement of Strengthening 21st Century Literacy in SMA/K PE Learning
}

\author{
Hendra Setyawan ${ }^{1, *}$ Jurumia Jurumia $^{2,}$ Martono Martono ${ }^{1,}$ Rina Yuniana ${ }^{1}$ \\ ${ }^{1}$ Faculty of Sport Science, Universitas Negeri Yogyakarta, Indonesia \\ ${ }^{2}$ SMA Muhammadiyah Kendari, Dikbud Southeast Sulawesi Province, Indonesia \\ *Corresponding author.Email: hendra7777setyawan@uny.ac.id
}

\begin{abstract}
This study aims to determine the effect of cooperative culture, discipline culture, and classroom management skills on the achievement of strengthening 21st-century literacy in Senior High School (SMA/K) PE learning in Southeast Sulawesi Province. This research is a type of correlational research with a quantitative approach to determine the relationship between two or more variables. Data collection techniques through questionnaires. The sample of this study was 40 respondents of $\mathrm{PE}$ teachers $\mathrm{SMA} / \mathrm{K}$ who were taken using the purposive sampling technique. The instruments in this study have been tested for validity and reliability, and have been consulted by experts. The data analysis technique uses regression analysis that has been tested for classical assumptions. Based on the results (T-test), the significant value of the cooperative culture variable is $0.133>0.05$, discipline culture is $0.048<0.05$ and class management skills is $0.000<0.05$. This means that partially the $\mathrm{X} 1$ variable has no effect on $\mathrm{Y}$, while the $\mathrm{X} 2$ and $\mathrm{X} 3$ variables have an effect on the Y variable. The ANOVA (F test) results obtained a significant value of 0.000 . This shows that the culture of cooperation, discipline culture, and classroom management skills simultaneously affect the achievement of strengthening 21 st-century literacy in SMA/K PE learning in the Southeast Sulawesi Province. In addition, the R square ${ }^{\circledR}$ value of 0.854 means that $85.4 \%$ of the achievement of strengthening 21 st-century literacy in PE SMA/K is influenced by a culture of cooperation, discipline culture, and classroom management skills.
\end{abstract}

Keywords: Culture, Cooperation, Discipline, Classroom management.

\section{INTRODUCTION}

Literacy is not just the ability to read and write, but literacy can mean technology literacy and critical thinking. These 21 st-century skills include critical thinking, creativity, collaboration, and 4C communication [1]. The call for educators around the world to prepare students for the 21 st century encourages educators to provide students with a holistic education that emphasizes life skills such as communication, crosscultural collaboration, and critical thinking [2]. 21stcentury learning is learning characterized by learning skills, skills, and literacy. Learning skills are learning activities in which are marked by cooperation, communication, and critical and creative thinking. This 21 st-century competence has been adapted in the education system in Indonesia through the Curriculum
2013 (K-13). The approach used in the K-13 is a scientific approach consisting of $(5 \mathrm{~m})$, namely observing, asking questions, experimenting, associating, and communicating [3].

Although the strengthening of literacy culture programmed for scientific learning in the K-13 has been running for several years, the reality on the ground shows that the literacy culture of students in Indonesia is still relatively low. Based on PIRLS and PISA data, especially in reading comprehension skills, it shows that the competence of Indonesian students is low [4]. Other countries in Asia, such as South Korea and Singapore, dominated the Program for International Student Assessment (PISA) achievements, while other countries from the East Asia region, including Malaysia, also 
experienced a slump in PISA's achievements, despite having spent large budgets. for the field of education [5].

To succeed in achieving the strengthening of 21 stcentury literacy in learning requires involvement from various parties. Principals and teachers synergize with each other to achieve the achievement of strengthening 21 st-century literacy as stated in the K-13. Involvement in this synergy must be realized by all subject teachers, including PE subject teachers who dominate practical activities in the field in order to maximize the curriculum program. 2013 on PE subjects. Therefore, a commitment is needed to maintain a good school culture.

School culture is part of the organizational culture in the world of education that should be able to set an example. School leaders and teachers must be ready to create a more multicultural school culture by learning to deal with students' ethnic differences [6]. Organizational culture is a key element in clarifying the sources of conflict and dealing with conflicts that escalate and recur [7]. Thus, there is a need to improve the culture of the school and its surroundings to support the teaching and learning process. The process of forming religious culture through two main strategies, namely: (a) logical educative strategy and (b) logical constructive strategy. The logical educative strategy is an attempt to put into practice aspects of structural instruction. While the logical constructive strategy is an effort to build a religious culture in schools [8].

The school culture which includes a culture of cooperation and a culture of discipline is part of the school's organizational culture which always needs to be preserved and improved. This is to support the achievement of educational goals in general and learning objectives in particular. Broadly speaking, there are factors that affect the quality of learning, including supporting factors which include the principal's leadership, coordination, and cooperation as well as teacher skills in managing the classroom [9].

To be able to achieve maximum educational and learning goals, of course, does not only require a culture of cooperation and a culture of discipline within a school organization, but also basic skills or skills related to professionalism as an educator or teacher. Skills that are very important as a booster for the success of learning are skills in teaching or managing classes. Teacher independence for classroom management is an important component of teacher identity which has implications for teaching quality [10]. For that, teachers need comprehensive professional development of various classroom management techniques. Teachers can also promote meaningful and culturally responsive participatory practices [11].

The relationship between a culture of cooperation, a culture of discipline, and classroom management skills is very close to being able to teach well. Especially in the application of the K-13 learning which contains 21stcentury skills that emphasize various skills, such as collaboration and 21st-century literacy. As an appeal for educators around the world to prepare students for the 21 st century, it encourages educators to equip students with a holistic education that emphasizes life skills such as communication, cross-cultural collaboration, and critical thinking [2]. Moreover, if it is applied in PE learning which is dominated by cooperative or collaborative activities through physical activity games. The contribution of PE in shaping 21st-century skills is very important because only PE facilitates students with a large portion of doing physical activity to achieve overall educational goals. The revised 2013 edition of the curriculum provides guidelines that today's PE learning is not only moving and having fun but also requires students to have critical thinking skills, be creative, innovative, able to collaborate, and communicate well. So the PE curriculum that is compiled will produce people who have health and skills in the 21 st-century era [12].

Broadly speaking, there are two factors that affect the quality of learning, including 1) Supporting factors which include the principal's leadership, coordination and cooperation, and teaching skills in managing the classroom, 2) Inhibiting factors include facilities and infrastructure, education budget, or financing and quality. low educators [9]. Moreover, in the K-13 PE learning which contains strengthening the 21 st-century literacy culture, it requires teachers who must be truly professional and have a high commitment to achieving learning goals. This is because in PE the curriculum content is not only about movement skills and physical health, but students are required to be able to think critically, creatively, and able to collaborate. The most prominent change in the 21 st-century physical education curriculum is that physical learning does not only involve sports equipment, but learning resources that come from modern technology packaging need to be provided [13].

Therefore, to be able to provide encouragement to achieve 21st-century literacy strengthening in PE learning Curriculum 2013 it is necessary to have a culture of cooperation, a culture of discipline, and also skills in classroom management. Based on some of these things, the researchers are interested in conducting research on the influence of a culture of cooperation, discipline culture, and classroom management skills on the achievement of strengthening 21st-century literacy in PE learning in Senior High School (SMA/K) in Southeast Sulawesi Province.

\section{METHOD}

\subsection{Participants}

The sample in this study was taken with a purposive sampling system. The sample of this research is 40 
respondents of $\mathrm{PE} \mathrm{SMA} / \mathrm{K}$ teachers from Southeast Sulawesi Province (Table 1).

Table 1. Major teacher respondent and number of $\mathrm{sma} / \mathrm{k}$

\begin{tabular}{|c|c|c|}
\hline No & Districs/City & Respondent PE Teachers \\
\hline 1 & Kendari & 20 \\
\hline 2 & Buton & 3 \\
\hline 3 & Muna Kota Raha & 3 \\
\hline 4 & Kolaka & 6 \\
\hline 5 & Konawe & 7 \\
\hline 6 & Bau Bau & 1 \\
\hline \multicolumn{2}{|r|}{ Total } & 40 \\
\hline
\end{tabular}

\subsection{Procedure}

This research belongs to the type of correlational research, which is a study to determine the relationship and level of relationship between two or more variables. This study uses a quantitative approach.

The variables in this study consisted of three independent variables, namely the cooperative culture variable $(\mathrm{X} 1)$, the discipline culture variable (X2), the classroom management skill variable (X3) and the dependent variable, namely the achievement of $21 \mathrm{st}$ century literacy strengthening in SMA/K PE learning (Y).

\subsection{Data Collection}

The data collection technique used in this study is a Likert scale questionnaire $1-4$. The instrument used has been tested for validity and reliability. The instrument on the cooperative culture variable (X1) consists of 7 items which are then declared valid 6 question items because they have an r-count $>$ r-table 0.312 and a Sig value. $<0.05$ at the $5 \%$ significance level. The instrument on the discipline culture variable (X2) consists of 7 question items which are then declared valid all because they have an $r$-count $>$ r-table 0.312 and a Sig value. $<0.05$ at the $5 \%$ significance level. The instrument on the class management skill variable (X3) consists of 7 question items which are then declared valid, all of which have an r-count $>$ r-table 0.312 and a Sig value. $<0.05$ at the $5 \%$ significance level. The instrument on the achievement variable for strengthening 21st-century literacy in SMA/K (Y) PE learning consists of 7 question items which are then declared valid, all of which have an $r-$ count value $>$ r-table 0.312 and a Sig value. $<0.05$ at the $5 \%$ significance level. The instrument has been prepared by the researcher according to the context to be studied and has been consulted with experts.

Instruments that have been declared valid are then tested for Cronbach's alpha reliability. The results of the variable reliability test (X1) all items have a value of 0.692 with 6 question items, so that Cronbach's alpha value of $0.692>0.60$ is declared reliable or consistent. In the variable (X2) Cronbach's alpha value of all items is 0.688 with 7 question items, so the value of $0.688>0.60$ is declared reliable. In the variable (X3) Cronbach's alpha value of all items is 0.787 with 7 question items, so the value of $0.787>0.60$ is declared reliable. In the variable (Y) Cronbach's alpha value of all items is 0.835 with 10 question items, so the value of $0.835>0.60$ is declared reliable.

\subsection{Data Analysis}

The data analysis technique in this study used simple linear regression analysis and multiple linear regression using SPSS software. The steps of data analysis include: (1) classical assumption testing includes normality test, linearity test, multicollinearity test, and heteroscedasticity test; (2) partial simple linear regression analysis (T-test); (3) simultaneous multiple linear regression analysis (F test) Anova; and (4) analysis of the coefficient of determination.

\section{RESULTS}

\subsection{Classic Assumption Test}

Based on the results of the first classical assumption test, namely the normality test, it is known that the significance value (2-tailed) is $0.824>0.05$, so it can be concluded that the residual value is normally distributed. Based on the results of the second classical assumption test, namely the linearity test, it has been found that the $\mathrm{X} 1$ variable has a Sig value. Deviation From Linearity is $0.748>0.05$. The variable $\mathrm{X} 2$ has a value of Sig. Deviation From Linearity is $0.963>0.05$. The variable $\mathrm{X} 3$ has a value of Sig. Deviation From Linearity is 0.224 $>0.05$. Thus the variables $\mathrm{X} 1, \mathrm{X} 2$, and $\mathrm{X} 3$ to $\mathrm{Y}$ are linear. Based on the results of the third classical assumption test, namely the multicollinearity test, it has shown that the Tolerance value of the variable $\mathrm{X} 1=0.588, \mathrm{X} 2=0.604$ and $\mathrm{X} 3=0.961>0.100$ and the VIF value of the variable $\mathrm{X} 1=1.702, \mathrm{X} 2=1.655$ and $\mathrm{X} 3=1.040<10.00$ then the conclusion is that there is no multicollinearity in the regression model. Based on the results of the fourth classical assumption test, namely the heteroscedasticity test, it has shown that the significance value ( $\mathrm{Sig}$ ) of the $\mathrm{X} 1$ variable $=0.757>0.05$, the $\mathrm{X} 2$ variable $=0.172>$ 0.05 , and the $\mathrm{X} 3$ variable $=0.548>0.05$, so this study free from heteroscedasticity and deserves to be studied. Based on the results of all classical assumption tests which include normality test, linearity test, multicollinearity test, and heteroscedasticity test above, the linear regression model has met the requirements for partial (T-test) and (F-test) simultaneous, and coefficient analysis determination.

\subsection{Partial T-Test}

The results of this study indicate (T-test) partially the variable (X1) obtains a T-count value of $1.535<\mathrm{T}$-table 2.028 and a Sig. $0.133>0.05$. Thus Ho is accepted and $\mathrm{Ha}$ is rejected, indicating that the cooperative culture variable (X1) has no significant effect on the 
achievement of 21st-century literacy strengthening in SMA/K PE learning (Y). Then (T-test) partially the variable (X2) obtained a T-count value of $-2.045>\mathrm{T}$ table 2.028 and a significance value of $0.048<0.05$. Thus $\mathrm{Ho}$ is rejected and $\mathrm{Ha}$ is accepted, indicating that the disciplined culture variable (X2) has a negative and significant effect on the achievement of 21 st-century literacy strengthening in SMA/K PE learning (Y). As for the results (T-test) partially the variable (X3) obtained a T-count value of $14,153>$ T-table 2,028 and a significance value of $0.000<0.05$. Thus Ho is rejected and $\mathrm{Ha}$ is accepted, indicating that the variable classroom management skills (X3) have a positive and significant effect on the achievement of strengthening 21st-century literacy in PE learning in SMA/K in Southeast Sulawesi Province (Y).

\subsection{Simultaneous F Test}

The results ( $\mathrm{F}$ Test) of ANOVA show that the significance value for the simultaneous effect of the variables $\mathrm{X} 1, \mathrm{X} 2$, and $\mathrm{X} 3$ on (Y) is the value of Sig. 0.000 $<0.05$ and the F-count value of $70.172>$ F-table 2.92 . Thus, it can be concluded that the variables of cooperative culture (X1), discipline culture (X2), and classroom management skills (X3) simultaneously affect the achievement variable of 21st-century literacy strengthening in $\mathrm{SMA} / \mathrm{K}$ PE learning in Southeast Sulawesi Province (Y) (Table 2).

Table 2. Anova test

\begin{tabular}{|c|l|c|c|c|c|c|}
\hline \multicolumn{2}{|c|}{ Model } & $\begin{array}{c}\text { Sum of } \\
\text { Squares }\end{array}$ & df & $\begin{array}{c}\text { Mean } \\
\text { Square }\end{array}$ & F & Sig. \\
\hline \multirow{2}{*}{1} & Regression & 422.798 & 3 & 140.933 & 70.172 & $.000^{\mathrm{a}}$ \\
\cline { 2 - 7 } & Residual & 72.302 & 36 & 2.008 & & \\
\cline { 2 - 7 } & Total & 495.100 & 39 & & & \\
\hline
\end{tabular}

\subsection{Coefficient of Determination}

The result of $\mathrm{R}$ square shows a value of 0.854 which means that the variables of cooperative culture, discipline culture, and classroom management skills are able to influence the achievement of strengthening 21st-century literacy in PE SMP learning in Southeast Sulawesi Province by $85.4 \%$. Meanwhile, $14.6 \%$ is influenced by other variables outside this study (Table 3 ).

Table 3. Summary model

\begin{tabular}{|c|c|c|c|c|}
\hline Model & $\mathbf{R}$ & R Square & $\begin{array}{c}\text { Adjusted R } \\
\text { Squre }\end{array}$ & $\begin{array}{c}\text { Std. Error of } \\
\text { the Estimate }\end{array}$ \\
\hline 1 & $.924^{\mathrm{a}}$ & .854 & .842 & 1.417 \\
\hline
\end{tabular}

\section{DISCUSSION}

\subsection{Effect of $X 1$ on $Y$}

The results of the value (T-test) for the cooperative culture variable in this study obtained a value of 1.535 with a significance value of 0.133 . Thus, the first hypothesis which reads "There is a partial influence of cooperative culture on the achievement of strengthening 21 st-century literacy in PE learning in $\mathrm{SMA} / \mathrm{K}$ in Southeast Sulawesi Province" is rejected. The culture of cooperation in an educational institution is part of the organizational culture that needs to be preserved. As for the results of research on the cooperative culture variable, the results of which are concluded to have no effect, it is contrary to the results of the research [14] which shows that organizational culture affects teacher performance in SMK. In addition, the results of research [15] also concluded that organizational culture has a significant effect on teacher performance in SMA and SMK.

\subsection{Effect of $X 2$ on $Y$}

The results of the value (T-test) for the disciplined culture variable obtained a value of -2.045 with a significance value of 0.048 . The negative regression coefficient means that the influence that arises in this study is not unidirectional, where if the culture of cooperation is good, then the achievement of strengthening 21st-century literacy in SMA/K PE learning decreases, and vice versa. Because the significance value is less than 0.05 , therefore, Ho is rejected and $\mathrm{Ha}$ is accepted. And it can be interpreted that the variable of disciplinary culture partially has a significant effect on the achievement of strengthening 21 st-century literacy in PE learning in SMA/K. This is supported by the results research [16] that work discipline has a significant effect on teacher performance. In addition, the research results of [17] concluded that work discipline, work motivation, and organizational culture have a positive effect on teacher performance. This research has contributed as input for schools to manage and maintain a school culture that can improve work discipline so that it can lead to an increase in teacher performance in the form of achieving a 21st-century literacy strengthening program in K-13 learning. Partial discipline culture towards the achievement of strengthening 21st-century literacy in SMA/K PE learning in Southeast Sulawesi Province" is declared accepted.

\subsection{Effect of X3 on $Y$}

The results of the value (T-test) for the class management skill variable obtained a value of 14,153 with a significance value of 0.000 . The positive regression coefficient means that the influence that arises in this study is unidirectional, where if the culture of cooperation is good, the achievement of strengthening 21st-century literacy in PE learning in SMA/K will increase, and vice versa. Because the significance value is less than 0.05 , therefore, Ho is rejected and $\mathrm{Ha}$ is accepted. Thus, it can be interpreted that the variable of classroom management skills partially has a significant effect on the achievement of strengthening 21st-century literacy in PE learning in SMA/K. This is corroborated by the results of research [18] that classroom management and work ethic affect the 
effectiveness of learning. In addition, it is also supported by the research results of [19] which concluded that classroom management skills affect students' learning motivation. So, the second hypothesis which reads "There is a partial effect of classroom management skills on the achievement of strengthening 21st-century literacy in SMA/K PE learning in Southeast Sulawesi Province" is accepted.

\subsection{Effect of $X 1, X 2$, and $X 3$ on $Y$}

Based on the results (F Test) ANOVA in research has shown a culture of cooperation (X1), a culture of discipline (X2), and classroom management skills (X3) together have an effect on the achievement of strengthening 21st-century literacy in SMA/K PE learning (Y). Based on the results of the ANOVA table, the value is 0.000 . In conclusion, the three independent variables jointly affect the achievement of strengthening 21st-century literacy in PE learning in $\mathrm{SMA} / \mathrm{K}$ in Southeast Sulawesi Province. This is also supported by the results of the R-square (R2) value of 0.854 , meaning that $85.4 \%$ of the achievement of strengthening $21 \mathrm{st}-$ century literacy in PE SMA/K learning is influenced by the variables of cooperative culture, discipline culture, and classroom management skills. While $14.6 \%$ is influenced by other variables. This is reinforced by the results of research [14] which shows that organizational culture affects teacher performance in SMK. In line with this, [16] also shows that work discipline has a significant effect on teacher performance. The research of [18] also concludes that classroom management and work ethic affect the effectiveness of learning. Thus, the first hypothesis reads "There is a simultaneous influence of a cooperative culture, discipline culture, and classroom management skills on the achievement of 21 st-century literacy strengthening in $\mathrm{SMA} / \mathrm{K}$ PE learning in Southeast Sulawesi Province" is declared accepted.

\section{CONCLUSION}

Based on the results of the discussion conducted by the researchers, it can be concluded: (1) The culture of cooperation partially does not affect the achievement of strengthening 21st-century literacy in PE learning in SMA/K in Southeast Sulawesi Province. (2) The culture of discipline partially affects the achievement of strengthening 21st-century literacy in PE SMA/K learning in Southeast Sulawesi Province. The influence that occurs is a negative influence, so the direction of the influence is not in the same direction. (3) Classroom management skills partially affect the achievement of strengthening 21st-century literacy in SMA/K PE learning in Southeast Sulawesi Province. The effect that occurs is a positive influence so that the direction of the influence is in the same direction. (4) The culture of cooperation, discipline culture, and classroom management skills simultaneously affect the achievement of strengthening 21st-century literacy in SMA/K PE learning in Southeast Sulawesi Province.

\section{ACKNOWLEDGMENTS}

The author would like to thank all the leaders of Yogyakarta State University (UNY)) who have given research permits with the issuance of SK Number 73/UN34.16/PT.01.01/2021. The authors also thank the Institute for Research and Community Service (LPPM) UNY for the financial support in this research. We would also like to thank the PE Teachers of SMP in Bantul and Gunung Kidul Districts, Yogyakarta.

\section{REFERENCES}

[1] T. Tang, V. Vezzani, and V. Eriksson, "Developing Critical Thinking, Collective Creativity Skills And Problem Solving Through Playful Design Jams," Think. Ski. Creat., vol. 37, no. July, p. 100696, 2020.

[2] P. Teo, "Teaching For The 21st Century: A Case For Dialogic Pedagogy," Learn. Cult. Soc. Interact., vol. 21, no. January, pp. 170-178, 2019.

[3] S. N. Pratiwi, C. Cari, and N. S. Aminah, "Pembelajaran IPA Abad 21 Dengan Literasi Sains Siswa," J. Mater. dan Pembelajaran Fis., vol. 9, pp. 34-42, 2019.

[4] Kementrian Pendidikan dan Kebudayaan, "Desain Induk Gerakan Literasi Sekolah,” Kemdikbud, Jakarta, 2016.

[5] L. D. H. Perera and M. N. Asadullah, "Mind The Gap: What Explains Malaysia's Underperformance In Pisa?," Int. J. Educ. Dev., vol. 65, pp. 254-263, Mar. 2019.

[6] R. Vervaet, M. Van Houtte, and P. A. J. Stevens, "Multicultural School Leadership, Multicultural Teacher Culture And The Ethnic Prejudice Of Flemish Pupils," Teach. Teach. Educ., vol. 76, pp. 68-77, Nov. 2018.

[7] R. A. Louis and P. Christelle, "Managing Conflicts In The Nonprofit Sector Through Organizational Culture Change," Journal of Organizational Change Management, vol. aheadof-p, no. ahead-of-print. 01-Jan-2018.

[8] I. S. Wekke and A. Sahlan, "Strategy In Creating School Environment: Lessons From High Schools In Indonesia," Procedia - Soc. Behav. Sci., vol. 143, pp. 112-116, Aug. 2014.

[9] K. S. Siagian, "Implementasi Fungsi-Fungsi Manajemen Kepala Madrasah Untuk Meningkatkan Mutu Pembelajaran Guru Di Mts Nurul Iman," HIJRI - J. Manaj. Pendidik. dan Keislam., vol. 7, no. 2, pp. 101-109, 2018.

[10] R. Lazarides, H. M. G. Watt, and P. W. Richardson, “Teachers' Classroom Management Self-Efficacy, Perceived Classroom Management And Teaching Contexts From Beginning Until Mid-Career," Learn. Instr., vol. 69, p. 101346, Oct. 2020.

[11] L. M. Gaias, S. L. Johnson, J. H. Bottianic, K. J. Debnam, and C. P. Bradshawc, 'Examining Teachers' Classroom Management Profiles: Incorporating A Focus On Culturally Responsive Practice," J. Sch. Psychol., vol. 76, pp. 124-139, Oct. 2019.

[12] P. S. Mustafa, "Kontribusi Kurikulum Pendidikan Jasmani, Olahraga, dan Kesehatan di Indonesia dalam Membentuk Keterampilan Era Abad 21," J. Pendidik. Ris. Konseptual, vol. 4 , no. 3, pp. 437-452, 2020.

[13] P. S. Mustafa and W. D. Dwiyogo, "Kurikulum Pendidikan Jasmani, Olahraga, dan Kesehatan di Indonesia Abad 21," 
JARTIKA J. Ris. Teknol. dan Inov. Pendidik., vol. 3, no. 2, pp. 422-438, 2020.

[14] N. Z. Susan Febriantina, Febi Nur Lutfiani, "Pengaruh Budaya Organisasi Terhadap Kinerja Guru," Tadbir Muwahhid, vol. 2, no. 2, 2018.

[15] A. P. Sari, S. Ahmad, and H. Harris, "Pengaruh Budaya Organisasi dan Motivasi Kerja Terhadap Kinerja Guru," Jambura, vol. 2, no. 2, 2021.

[16] R. N. Suryadi, "Pengaruh Budaya Organisasi, Motivasi Kerja Dan Disiplin Kerja Terhadap Kinerja Guru Sma Negeri Di Kota Makassar," Indones. J. Econ. Entrep. Innov., vol. 1, no. $1,2020$.

[17] D. W. Virsa Sari Widuri, Innocentius Bernarto, "Pengaruh Disiplin Kerja, Motivasi Kerja, dan Budaya Organisasi terhadap Kinerja," J. Adm. Bisnis, vol. 10, no. 2, 2020.

[18] M. Y. Patmawati Patmawati, Muh. Yunus, Rego Devilla, "Pengaruh Manajemen Kelas Dan Etos Kerja Guru Terhadap Efektivitas Pembelajaran Di Smp Negeri 1 Parepare," J. Ilm. Pena, vol. 10, no. 2, 2018

[19] O. O. Cici Andini, Achmadi Achmadi, "Pengaruh Keterampilan Pengelolaan Kelas Terhadap Motivasi Belajar Di Sma Negeri 4 Sungai Raya," KHATULISTIWA, vol. 10, no. 4, 2021. 